Original Research Paper

\title{
Epidemiological Study on the Current Status of Rice Tungro Disease in South Sulawesi, Indonesia
}

\author{
${ }^{1,2}$ Nur Rosida, ${ }^{1}$ Tutik Kuswinanti, ${ }^{1}$ Nur Amin and ${ }^{1}$ Andi Nasruddin \\ ${ }^{I}$ Department of Plant Pest and Disease, Faculty of Agriculture, Hasanuddin University, Makassar, Indonesia 90245 \\ ${ }^{2}$ Indonesian Rice Tungro Research Center, Lanrang, Sidenreng Rappang, South Sulawesi, Indonesia 91651
}

\author{
Article history \\ Received: 07-09-2020 \\ Revised: 01-12-2020 \\ Accepted: 02-12-2020 \\ Corresponding Author: \\ Andi Nasruddin \\ Department of Plant Pest and \\ Disease, Faculty of Agriculture, \\ Hasanuddin University, \\ Makassar, Indonesia 90245 \\ E-mail: swetaparimitabera@gmail.com
}

\begin{abstract}
Integrated management of Rice Tungro Disease (RTD) by combining the appropriate planting time and cultivar rotation has successfully controlled the disease in South Sulawesi, Indonesia. By the early 1990's, about 10 years after the management was implemented, tungro disease incidence was so low that the integrated management was no longer strictly implemented and eventually abandoned. Surprisingly however, the tungro incidence steadily decreases in the area ever since. Therefore, the purpose of the study was to elucidate why the rice tungro disease incidence decreases even when the integrated management is no longer in place. A series of studies was conducted to determine the adaptability of rice Green Leafhopper (GLH), Nephotettix virescens, colonies on different cultivars with different resistance genes against the leafhopper, tungro transmission efficiency in laboratory and in field and tungro viruses (RTBV and RTSV) detection in weeds. The results indicated that all GLH colonies had adapted to all cultivars carrying different GLH resistance genes. For each colony, there were no significant differences between the resistant cultivars and TN-1 (no GLH resistance gene) in: (1) Percent of first instars developing to the second instar nymphs, (2) nymphal development indices, (3) tungro virus transmission efficiency and (4) GLH populations. The PCR results showed that none of the weeds tested contained the rice tungro viruses. Therefore, the study results suggested that the lack of rice tungro inoculums in the weeds was the main reason why tungro incidence decreases from time to time. However, if the rice tungro viruses are reintroduced to the region, the RTD can become devastating because the GLH colonies have already adapted to all available resistance genes. Further studies should be conducted to find and incorporate new resistance genes into commercial cultivars.
\end{abstract}

Keywords: Integrated Management, Rice Tungro Virus, RTBV, RTSV

\section{Introduction}

Rice Tungro Disease (RTD) is a major limiting factor of rice production, widely distributed in South and Southeast Asia (Bunawan et al., 2014). In Indonesia, during the period of 1969-1983, 168,000 ha of rice was damaged by the disease throughout the country, of which about 100,000 ha occurred in South Sulawesi from 1972-1975 (Hibino, 1987). The disease is caused by dual infection of the Rice Tungro Spherical Virus (RTSV) (Family: Sequiviridae) and the Rice Tungro Bacilliform Virus (RTBV) (Family: Caulimoviridae) (Tiongco and Sebastian, 2008; van Regenmortel et al., 2000). The viruses are semi-persistently transmitted by several species of the rice Green Leafhopper (GLH) (Hemiptera: Cicadellidae) (Hibino et al., 1978) and among which Nephotettix virescens (Dist.) is the most efficient vector species (Yuliani, 2014). Besides that, the presence of a less efficient vector species of the viruses, $N$. nigropictus Stal., has also been reported in South Sulawesi (Widiarta, 2005; Nasruddin et al., 2016).

During the fallow period between planting seasons when rice plants are not available in the field, the tungro viruses and their vectors survive on different weed species. From the weeds, the viruses are transmitted to new plants in the next season (Ladja, 2013). Anjaneyulu et al. (1982) 
reported that some weed species could harbor the tungro viruses and acted as inoculum sources for the next season. Several weed species have been reported as alternative hosts of the virus in Indonesia, such as Cyperus rotundus, Monochoria vaginalis, C. rotundus, Phyllanthus niruri, Fimbristylis miliaceae and Eulisine indica (Ladja, 2013). Therefore, weeds play an important role in the rice tungro disease epidemiology because the rice tungro viruses are not seed-borne.

An integrated management of tungro disease was implemented by combining appropriate planting time and varietal rotation (Praptana and Muliadi, 2013; Widiarta et al., 2013). The planting time was planned in such a way that the susceptible life stage of the plant to tungro infection ( $<45$ days after transplanting) was not coincident with the occurrence of high vector population and the abundance of virus inoculum in the field. In addition, the rice varieties were rotated between planting seasons, based on their resistant genes against the GLH to prevent the insect from adapting to a certain resistance gene. Resistant genes to GLH used in the cultivar rotation scheme were Glh-1, glh-4, Glh-5 and Glh-6. Cultivars without resistance gene were also incorporated into the scheme (Burhanuddin et al., 2006). The management effort was firmly implemented by the farmers under the local government's close supervision. For example, in both 1985 and 1986, 95.6\% of rice area was planted on the recommended schedule. Similarly, for the same years, 78 and $85 \%$ of the area, respectively, were planted with recommended varieties in the cultivar rotation practice (Sama et al., 1991).

The integrated approach effectively suppressed the GLH population and rice tungro incidence. Average populations of the GLH before and after the implementation of the management were about 620 and 430 individuals per 10 sweeps, respectively (Sama et al., 1991). Similarly, rice tungro incidence substantially decreased from 9,700 ha (1982) to 325 ha/year (2004-2011) damaged by the disease before and after the integrated management was applied, respectively (Burhanuddin, 2006). The GLH population and rice tungro incidence continuously declined as the integrated management was implemented and in consequence, the recommendations became loosened and eventually abandoned in early 1990 's. Since then, farmers can plant whenever water is available and whatever cultivars they like. Surprisingly however, the tungro has become less important even when planting time and varietal rotation recommendations are no longer in place. From 20112019, an average of 24.5 ha, ranging from $0-85$ ha per year of plantation was damaged by tungro. In 2015 and 2019, no tungro damage was reported in the whole province's 648,900 ha of rice paddy (BBPOPT, 2019; DITLIN, 2019; PUSDATIN, 2017). The present epidemiological study was therefore, conducted to elucidate why the rice tungro disease incidence steadily decreases even when the recommendations for the appropriate planting time and varietal rotation schemes are no longer implemented in the area. The information obtained may be of use in managing other similar plant disease complexes and anticipating the possibility of the tungro epidemic reoccurs in the future.

\section{Materials and Methods}

\section{Collection and Rearing of the Insect Vector}

The adults of the GLH, N. virescens, were collected using a sweep net (42 cm in diam.) from four regencies: Pinrang, Sidenreng Rappang (Sidrap), Gowa and Maros in South Sulawesi Province, Indonesia, in August 2018. Regencies of Pinrang and Sidenreng Rappang (Sidrap) (Burhanuddin, 2006; Suprihanto et al., 2013) are known as rice tungro disease endemic areas while Gowa and Maros are non-endemic areas. The GLH collected from Pinrang, Sidrap, Gowa and Maros were designated as Pinrang colony, Sidrap colony, Gowa colony and Maros colony, respectively, in this study. In each regency, the leafhoppers were collected from 4-5 sample points, which were 5 to $10 \mathrm{~km}$ apart (Table 1). The collected insects were immediately transferred onto three weeks old rice plants cv. TN-1 (no resistance gene against the GLH). The colonies were caged separately and then brought to the Insectary of the Indonesian Rice Tungro Research Center, Lanrang, Sidenreng Rappang for mass rearing. The rearing of the insects and the experiments were conducted in the screen house under $30 \pm 2^{\circ} \mathrm{C}$ and with about 12L:12D photoperiod. Ten pairs of adults were transferred onto 21 days old rice plants cv. TN-1. The GLH colonies coming from different regencies were caged separately in aluminum-framed cages $(40 \times 25 \times 40 \mathrm{~cm})$. The adults were moved to new plants for oviposition every seven days in order to assure the availability of first instar larvae and newly formed adults when they were needed for the trials.

\section{Percent of the First Instar Developing to the Second Instar Nymphs}

The adaptability or virulence of GLH colony to a resistant rice cultivar can be assessed by comparing the percent of the first instar nymphs developing to the second instar nymphs between $\mathrm{TN}-1$ and the resistant cultivars (Hirae et al., 2007). A two-leaf stage of rice seedling was placed inside of a reaction tube $(0.75 \mathrm{~cm}$ in diameter, $18 \mathrm{~cm}$ in length), containing $2 \mathrm{~mL}$ of water. Five new first instar nymphs were released into the tube before the tube was plugged with a cotton ball. Ten seedlings were tested for each treatment combination of colony and cultivar. Daily observations were conducted to determine the percent of nymphs molting into the second instar nymphs. A GLH colony is considered 
has adapted to a resistant cultivar if the percent of the first instar developing to the second instar on the resistant cultivar is not significantly different from $\mathrm{TN}-1$.

\section{Nymphal Duration, Survival Rate and Development Index}

Nymphal duration, nymphal survival and nymphal development index were determined using the methods of (Heinrichs, 1985; Azzam et al., 2000; Hirae et al., 2007). For each colony, ten newly emerging first instar nymphs were transferred to each of 15 cylindrical vinyl chloride cages $(17 \mathrm{~cm}$ diameter $\times 35 \mathrm{~cm}$ height), each contained 30 young rice seedlings (10 days after sown). Of the 15 cages, three cages were designated as replications for each of the cultivar used for selection. There were five cultivars with different resistant genes against the GLH used in this experiment, namely: TN-1 (no resistance gene), IR 46 (Glh-1 gene), Ciliwung (Glh-6 gene), IR 48 (Glh-5 gene) and IR 66 (glh-4 gene). Except for Gowa colony, only three cultivars were tested: TN-1, IR 48 and IR 66 because seedlings for IR 46 and Ciliwung were not available enough to run the test. The seedlings were replaced with new seedlings every five days to provide fresh food for the insect until they became adults. The insect development was observed daily until no more adults formed in each cage. The average of nymphal duration and percent of nymphal survival were calculated. In addition, the nymphal Development Index (DI) was also determined using the following equation (Cook, 1991):

$$
D I=\frac{\text { \%nymphal survival }}{\text { Meannymphal duration }(\text { days })}
$$

\section{Transmission Efficiency Test}

Efficiency of each of the GLH colonies in transmitting RTV to different cultivars with different resistance genes to GLH, TN-1 (no resistance gene), IR 46 (Glh 1), Ciliwung (Glh 5), IR 48 (Glh 6) and IR 66 (glh-4) was evaluated using a no-choice seedling test, following the method of (Widiarta et al., 2013). Adult population of each colony were placed into an aluminum-framed cage $(4025 \times 40 \mathrm{~cm})$, containing RTV-infected plants for a $24 \mathrm{~h}$ acquisition feeding. Two viruliferous insects were then transferred into a cage containing a ten-day old seedling for a $24 \mathrm{~h}$ inoculation feeding. For each cultivar, 10 seedlings were tested. Percent of RTV-infected plants assessed 21 days after inoculation and cultivar reaction to the GLH colonies were evaluated based on the method of (Azzam et al., 2000).

Cultivar reactions to the GLH are grouped into three categories: Susceptible (61-100\% infection), moderately resistant (31-60\% infection) and resistant (0-30\% infection). Adaptability of the colonies on the resistant cultivars was also assessed in this experiment. A colony of the GLH is considered adaptable or virulent to a certain resistant gene if the percentage of the infection on the cultivars carrying the resistance gene is not significantly different from the infection rate on $\mathrm{TN}-1$ (no resistance gene). On the other hand, if the infection rate on the resistant cultivar is significantly lower than on $\mathrm{TN}-1$, the colony is not adaptable to the cultivar (Widiarta et al., 2004; Widiarta et al., 2013; Hirae et al., 2007).

\section{Field Experiment}

A field experiment was conducted in the Experiment Station of the Indonesian Rice Tungro Research Center to determine the GLH virulence and tungro transmission on different rice cultivars with different resistance genes against the GLH. Treatments consisted of five rice cultivars: Pelita (no resistance gene), IR 46 (Glh 1), Ciliwung (Glh6), IR 64 (Glh 5) and IR 66 (glh 4). The treatments were arranged in a complete randomized block design with four replications. Each replication consisted of a plot of $4 \times 6 \mathrm{~m}$ with a planting space of $25 \times 25 \mathrm{~cm}$. There was a $2 \mathrm{~m}$ empty space between plots. Three weeks old seedlings were transplanted to the field. The plots' perimeters were planted with one row of RTVinfected plants as inoculum source. The rice green leafhopper, $N$. virescens infestation occurred naturally. No insecticides were applied in the experimental site during the season. Four weekly observations were conducted on 21 (14 July), 28 (21 July), 35 (28 July) and 42 (4 August) days after transplanting to determine the number of GLH adults caught per 20 strokes of sweep net in each plot. On each observation date, the number of RTV-infected hills were also counted to determine the incidence of RTV infection per plot.

\section{Detection of Rice Tungro Viruses in Weeds}

To detect the presence of RTBV and RTSV in weeds, samples were collected from the same locations for the GLH colony collection as described in Table 1 . One sample of each weed species encountered in each sampling location was randomly selected and carefully removed from the field and then immediately replanted in separate caged pots, containing a mixture of soil and organic matter (2:1). The weed samples were maintained in a greenhouse room at the Indonesian Rice Tungro Disease Research Center until they were processed further for RTV detection using a PCR method in the laboratory. 
Table 1: Sampling sites for collecting GLH colonies and weeds in four regencies in South Sulawesi, Indonesia

\begin{tabular}{|c|c|}
\hline Sampling site & Coordinate \\
\hline \multicolumn{2}{|l|}{ Pinrang Regency } \\
\hline To’e & 3०51'13”S, 11943'18”E \\
\hline Salo & $3^{\circ} 48^{\prime} 04^{\prime \prime S}, 119^{\circ} 37^{\prime} 41^{\prime \prime} \mathrm{E}$ \\
\hline Samaenre & $3^{\circ} 49^{\prime} 08^{\prime \prime} \mathrm{S}, 119^{\circ} 34^{\prime} 02^{\prime \prime} \mathrm{E}$ \\
\hline Benrange & $3^{\circ} 51^{\prime} 55^{\prime \prime} \mathrm{S}, 19^{\circ} 35^{\prime} 52^{\prime \prime} \mathrm{E}$ \\
\hline Bunga & $3^{\circ} 49^{\prime} 12^{\prime} \mathrm{S}, 119^{\circ} 35^{\prime} 27^{\prime \prime} \mathrm{E}$ \\
\hline \multicolumn{2}{|l|}{ Sidenreng Rappang (Sidrap) Regency } \\
\hline Ciro-Ciroe & $3^{\circ} 52^{\prime} 54^{\prime \prime S}, 119^{\circ} 45^{\prime} 25^{\prime \prime} \mathrm{E}$ \\
\hline Empagae & $3^{\circ} 55^{\prime} 04^{\prime \prime} \mathrm{S}, 119^{\circ} 51^{\prime} 49^{\prime \prime} \mathrm{E}$ \\
\hline Lawawoi & $3^{\circ} 54^{\prime} 32^{\prime \prime} \mathrm{S}, 119^{\circ} 44^{\prime} 58^{\prime \prime} \mathrm{E}$ \\
\hline Lanrang & $3^{\circ} 51^{\prime} 00^{\prime \prime} \mathrm{S}, 119^{\circ} 50^{\prime} 00^{\prime \prime} \mathrm{E}$ \\
\hline Akakae & $3^{\circ} 52^{\prime} 41^{\prime} \mathrm{S}, 119^{\circ} 51^{\prime} 34^{\prime \prime} \mathrm{E}$ \\
\hline \multicolumn{2}{|l|}{ Gowa Regency } \\
\hline Palangga & $5^{\circ} 13^{\prime} 44^{\prime \prime} \mathrm{S}, 119^{\circ} 26^{\prime} 24^{\prime \prime} \mathrm{E}$ \\
\hline Bontosunggu & $5^{\circ} 16^{\prime} 13^{\prime \prime} \mathrm{S}, 119^{\circ} 25^{\prime} 47^{\prime \prime} \mathrm{E}$ \\
\hline Panyangkalang & $5^{\circ} 19^{\prime} 08^{\prime \prime} \mathrm{S}, 119^{\circ} 26^{\prime} 16^{\prime \prime} \mathrm{E}$ \\
\hline Bajeng & $5^{\circ} 16^{\prime} 13^{\prime \prime} \mathrm{S}, 119^{\circ} 25^{\prime} 47^{\prime \prime} \mathrm{E}$ \\
\hline \multicolumn{2}{|l|}{ Maros Regency } \\
\hline Semangki & $5^{\circ} 2^{\prime} 14^{\prime \prime} \mathrm{S}, 119^{\circ} 41^{\prime} 29^{\prime \prime} \mathrm{E}$ \\
\hline Jene Tesa & $5^{\circ} 1^{\prime} 29^{\prime \prime} \mathrm{S}, 119^{\circ} 39^{\prime} 25^{\prime \prime} \mathrm{E}$ \\
\hline Kalabirang & $5^{\circ} 0^{\prime} 23^{\prime} \mathrm{S}, 119^{\circ} 39^{\prime} 34^{\prime \prime} \mathrm{E}$ \\
\hline Alatengae & 500'16”S, 119॰38’38”E \\
\hline
\end{tabular}

For RTBV and RTSV detections, the procedures described by (Ladja et al., 2016) was adopted. Rice Tungro Bacilliform Virus (RTBV) detection was initiated with the extraction of the total DNA from fresh leaves of the weed samples, followed by DNA amplification and visualization of the amplified DNA using electro-phoresis. Total DNA of the samples was extracted using Cethyl Trimethyl Ammonium Bromide (CTAB) method. A pair of specific primers: DA-F (5'GGAATTCCGGCCCTCAAAAAC CTAGAAG-3') and DA-R (5'GGGGGTACCCCCCTC CGATTTCC CATGTATG-3') were used to amplify the RTBV coat protein gene with a size of $1.400 \mathrm{bp}$. Amplification

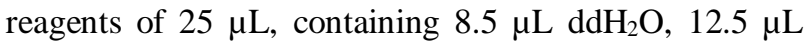
DreamTaq Green PCR Master mix (Thermo ScientificTM, US), $1 \mu \mathrm{L}$ primary DAR $10 \mu \mathrm{M}, 1 \mu \mathrm{L}$ primary DAF $10 \mu \mathrm{M}$ and $2 \mu \mathrm{L}$ DNA. The DNA amplification process began with a 5 -min initial denaturation at $94^{\circ} \mathrm{C}$, followed by 34 amplification cycles including $1 \mathrm{~min}$ denaturation at $94^{\circ} \mathrm{C}$, annealing for $1 \mathrm{~min}$ at $62.2^{\circ} \mathrm{C}$, synthesis for $2 \mathrm{~min}$ at $72^{\circ} \mathrm{C}$ and then added synthesis final step for $10 \mathrm{~min}$ at $72^{\circ} \mathrm{C}$. The amplification results were visualized with electrophoresis on $1 \%$ agarose gel (TBE) with ethidium bromide staining $(0.5 \mu \mathrm{g} / \mathrm{mL})$ for $\pm 15 \mathrm{~min}$.

Rice Tungro Spherical Virus (RTSV) detection was initiated with the extraction of the total RNA from fresh leaves of the weed samples, followed by reverse transcription to obtain complementary DNA (cDNA). Amplification of cDNA and visualization of the amplified cDNA were done by using a PCR procedure and electrophoresis, respectively. Total RNA of the samples was extracted using Cethyl Trimethyl Ammonium BROMIDE (CTAB) method. A pair of specific primers: RTSV-F2 (GAAGAAGCCT ATCATGTTCGCGT) and RTSV-R2 (CCTCCACGAT ATTGTACGAGG) were used to amplify the cDNA of the RTSV coat protein gene with a size of $787 \mathrm{bp}$. Amplification reagents of $25 \mu \mathrm{L}$, containing $8.5 \mu \mathrm{L}$ $\mathrm{ddH}_{2} \mathrm{O}, 12.5 \mu \mathrm{L}$ DreamTaq Green PCR Master mix (Thermo ScientificTM, US), $1 \mu \mathrm{L}$ primary RTSV-F2 10 $\mu \mathrm{M}, 1 \mu \mathrm{L}$ primary RTSV-R2 $10 \mu \mathrm{M}$ and $2 \mu \mathrm{L}$ cDNA. The cDNA amplification process began with a $5 \mathrm{~min}$ initial denaturation at $94^{\circ} \mathrm{C}$, followed by 34 amplification cycles including $1 \mathrm{~min}$ denaturation at $94^{\circ} \mathrm{C}$, annealing for $1 \mathrm{~min}$ at $62.2^{\circ} \mathrm{C}$, synthesis for $2 \mathrm{~min}$ at $72^{\circ} \mathrm{C}$ and then added synthesis final step for $10 \mathrm{~min}$ at $72^{\circ} \mathrm{C}$. The amplification results were visualized with electrophoresis on $1 \%$ agarose gel (TBE) with ethidium bromide staining $(0.5 \mu \mathrm{g} / \mathrm{mL})$ for $\pm 15 \mathrm{~min}$.

\section{Data Analysis}

Data of nymphal duration and survival, development index, transmission efficiency, GLH field population and tungro field incidence were subjected to Analyses of Variance (ANOVA) $(P=$ $0.05)$. Percentage data were transformed using arcsine before ANOVA. If significant differences were detected, then the treatment means were separated using Duncan's multiple range test $(P=0.05)$. 


\section{Results}

\section{Percent of the First Instar Developing to the Second Instar Nymphs}

There were no significant differences in the percentages of the first instar nymphs developing to the second instar nymphs for all colonies on different rice cultivars with different resistance genes against the GLH (Fig. 1). For Pinrang colony, the percentage of the first instar nymphs developing to the second instar nymphs on $\mathrm{TN}-1$ was $100 \%$ while the percentages on other cultivars ranged from $96-98 \%$. For Sidrap colony, the percentage of the first instar nymphs developing to the second instar nymphs on TN-1 was $100 \%$ while the percentages on other cultivars ranged from $84-100 \%$. For Gowa colony, the percentage of the first instar nymphs developing to the second instar nymphs on $\mathrm{TN}-1$ was $84 \%$ while the percentages on other cultivars ranged from $88-98 \%$. For Maros colony, the percentage of the first instar nymphs developing to the second instar nymphs on TN-1 was $96 \%$ while the percentages on other cultivars ranged from $88-100 \%$.

\section{Nymphal Duration, Nymphal Survival Rate and Development Index}

The nymphal duration, nymphal survival rate and development index of all GLH colonies on different rice cultivars with different resistance genes against the GLH are presented in Table 2. For each colony, although there were significant differences in GLH nymphal duration and nymphal survival rate on different cultivars, development indices on those cultivars were not significantly different from TN-1.

For Pinrang colony, the nymphal duration on IR 46 and Ciliwung were not significantly different from TN-1, while its nymphal duration on IR 48 and IR 66 was significantly longer and shorter, respectively, than the TN-1. The nymphal survival rates of the Pinrang colony on IR 46, Ciliwung and IR 48 were not significantly different from TN-1. In contrast, the GLH nymphal survival on IR 66 was significantly lower than the TN-1. However, the Pinrang colony's development indices on the cultivars were not significantly different from TN-1.

For Sidrap colony, the nymphal duration of the GLH on IR 46, IR 48 and IR 66 were not significantly different from $\mathrm{TN}-1$, while its nymphal duration on Ciliwung was significantly shorter than the TN-1. The nymphal survival rates of the Sidrap colony on IR 48 and IR 66 were not significantly different from $\mathrm{TN}-1$. In contrast, the GLH nymphal survival on IR 46 and Ciliwung were significantly lower than the TN-1.
However, the Sidrap colony's development indices on those cultivars were not significantly different from TN-1.

For Gowa colony, the nymphal duration of the GLH on IR 48 and IR 66 were not significantly different from $\mathrm{TN}-1$. The nymphal survival rates of the Gowa colony on IR 48 was significantly higher than TN-1 but its survival rate on IR 66 was significantly lower than the TN-1. However, the Gowa colony's development indices on the cultivars were not significantly different from $\mathrm{TN}-1$.

For Maros colony, the nymphal duration of the GLH on all cultivars was not significantly different from TN1. The nymphal survival rates of the Maros colony on IR 46 were not significantly different from $\mathrm{TN}-1$. While its survival rates on Ciliwung and IR 66 were significantly lower than the TN-1 but on IR 48 it was significantly higher than $\mathrm{TN}-1$. However, the colony's development indices on all cultivars were not significantly different from TN-1.

\section{Transmission Efficiency Test}

Transmission efficiencies of the rice tungro disease by four GLH colonies on five different cultivars with different resistant genes against the GLH are shown in Table 3. Tungro disease transmission by all colonies on all cultivars tested ranged from $50-100 \%$. Cultivars of TN-1, IR 46, Ciliwung and IR 48 were susceptible to Pinrang colony and the colony has adapted to those cultivars. However, IR 66 was moderately resistant to Pinrang colony and the colony has not adapted to the cultivar. All cultivars reacted susceptible to Sidrap and Gowa colonies and both colonies adapted to all cultivars. Cultivars of TN-1, IR 46, Ciliwung and IR 66 were susceptible to Maros colony and the colony was adapted to the cultivars. However, IR 48 was moderately resistant to Maros colony and the colony has not adapted well to the cultivar. However, none of the tested cultivars had a resistant reaction to any of the GLH colonies.

\section{Field Experiment}

The numbers of GLH adults per 20 sweeps and the incidence of rice tungro disease on four cultivars with different resistant genes against the GLH are shown in Fig. 2. Populations on all cultivars increased from the first observation date and reached their peaks at the third observation on 3 August and then dropped on 10 August. Similarly, cumulative rice tungro incidences increased from the first observation and reached their peaks on the third observation ( 3 Aug). During the experiment, there were no significant differences among the cultivars in the GLH population and tungro disease incidence for each observation date.

\section{Detection of Rice Tungro Virus in Weeds}

All weed species found in all sampling locations during the survey are shown in Table 4. The number and 
the species of weeds encountered during the survey varied amongst the sampling locations. The number of weed species collected in Pinrang, Sidrap, Gowa and
Maros were 10, 10, 5 and 9 species, respectively. The PCR results showed that none of the weed samples contained RTBV and/or RTSV Fig. 3.

Table 2: Nymphal duration (day), nymphal survival rate (\%) and development index (DI) on four rice cultivars with different resistance genes against the GLH, $N$. virescens

\begin{tabular}{lllll}
\hline GLH colony & Cultivar & $\begin{array}{l}\text { Mean }( \pm \text { SEM) } \\
\text { nymphal duration (days) }\end{array}$ & $\begin{array}{l}\text { Mean }( \pm \text { SEM) nymphal } \\
\text { survival rate (\%) }\end{array}$ & $\begin{array}{l}\text { Development index* } \\
\text { (day) }\end{array}$ \\
\hline Pinrang & TN1 & $25.1 \pm 0.6 \mathrm{~b}$ & $70.0 \pm 10.0 \mathrm{~b}$ & $2.7 \pm 0.5 \mathrm{a}$ \\
& IR 46 & $25.7 \pm 1.2 \mathrm{~b}$ & $73.3 \pm 8.8 \mathrm{~b}$ & $2.8 \pm 0.2 \mathrm{a}$ \\
& Ciliwung & $23.3 \pm 2.3 \mathrm{~b}$ & $73.3 \pm 8.8 \mathrm{~b}$ & $3.1 \pm 0.9 \mathrm{a}$ \\
& IR 48 & $32.1 \pm 0.7 \mathrm{c}$ & $73.3 \pm 8.8 \mathrm{~b}$ & $2.3 \pm 0.5 \mathrm{a}$ \\
& IR 66 & $15.2 \pm 0.2 \mathrm{a}$ & $30.0 \pm 5.8 \mathrm{a}$ & $2.0 \pm 0.4 \mathrm{a}$ \\
Sidrap & TN1 & $25.7 \pm 1.7 \mathrm{~b}$ & $60.0 \pm 5.8 \mathrm{c}$ & $23.9 \pm 2.5 \mathrm{~b}$ \\
& IR 46 & $23.9 \pm 2.5 \mathrm{~b}$ & $30.0 \pm 5.8 \mathrm{~b}$ & $1.4 \pm 0.1 \mathrm{a}$ \\
& Ciliwung & $17.5 \pm 0.3 \mathrm{a}$ & $23.3 \pm 3.3 \mathrm{a}$ & $1.3 \pm 0.8 \mathrm{a}$ \\
& IR 48 & $26.3 \pm 1.0 \mathrm{~b}$ & $50.0 \pm 5.8 \mathrm{c}$ & $1.9 \pm 0.4 \mathrm{a}$ \\
Gowa & IR 66 & $25.7 \pm 0.6 \mathrm{~b}$ & $40.0 \pm 5.8 \mathrm{bc}$ & $3.1 \pm 1.8 \mathrm{a}$ \\
& TN1 & $22.2 \pm 8.7 \mathrm{a}$ & $70.0 \pm 0.0 \mathrm{~b}$ & $25.7 \pm 1.7 \mathrm{a}$ \\
Maros & IR 48 & $35.0 \pm 8.7 \mathrm{a}$ & $86.7 \pm 3.3 \mathrm{c}$ & $1.4 \pm 0.5 \mathrm{a}$ \\
& IR 66 & $2.5 \pm 0.6 \mathrm{a}$ & $36.7 \pm 3.3 \mathrm{a}$ & $1.7 \pm 0.3 \mathrm{a}$ \\
& TN1 & $29.2 \pm 2.3 \mathrm{a}$ & $50.0 \pm 10.0 \mathrm{~b}$ & $1.3 \pm 0.3 \mathrm{a}$ \\
& IR 46 & $26.8 \pm 2.3 \mathrm{a}$ & $33.3 \pm 6.7 \mathrm{ab}$ & $1.0 \pm 0.3 \mathrm{a}$ \\
& Ciliwung & $28.0 \pm 2.0 \mathrm{a}$ & $26.7 \pm 8.8 \mathrm{a}$ & $2.3 \pm 0.5 \mathrm{a}$ \\
\end{tabular}

Numbers followed by the same letter in the same column are not significantly different for the same colony (Duncan's multiple range test, $p>0.05$ )

*Adapted = DI is not significantly different from TN-1, Not adapted = DI is significantly lower than TN-1

Table 3: Efficiency of different GLH colonies in transmitting rice tungro disease and reaction of the cultivars to the disease infection

\begin{tabular}{|c|c|c|c|c|c|}
\hline GLH colony & Cultivar & GLH resistant gene & $\begin{array}{l}\text { Tungro incidence } \\
(\%) \pm \text { SEM }\end{array}$ & $\begin{array}{l}\text { Cultivar } \\
\text { reaction* }\end{array}$ & $\begin{array}{l}\text { Colony } \\
\text { adaptability** }\end{array}$ \\
\hline \multirow[t]{5}{*}{ Pinrang } & TN1 & No resistant gene & $90.0 \pm 10.0 \mathrm{bc}$ & Susceptible & Adapted \\
\hline & IR 46 & Glh-1 & $80.0 \pm 13.3 \mathrm{ab}$ & Susceptible & Adapted \\
\hline & Ciliwung & Glh-6 & $100.0 \pm 0.0 \mathrm{c}$ & Susceptible & Adapted \\
\hline & IR 48 & Glh-5 & $80.0 \pm 13.3 \mathrm{ab}$ & Susceptible & Adapted \\
\hline & IR 66 & glh-4 & $60.0 \pm 16.3 \mathrm{a}$ & Moderately resistant & Not adapted \\
\hline \multirow[t]{5}{*}{ Sidrap } & $\mathrm{TN} 1$ & No resistant gene & $90.0 \pm 10.0 \mathrm{a}$ & Susceptible & Adapted \\
\hline & IR 46 & Glh-1 & $100.0 \pm 0.0 \mathrm{a}$ & Susceptible & Adapted \\
\hline & Ciliwung & Glh-6 & $90.0 \pm 10.0 \mathrm{a}$ & Susceptible & Adapted \\
\hline & IR 48 & Glh-5 & $100.0 \pm 0.0 \mathrm{a}$ & Susceptible & Adapted \\
\hline & IR 66 & glh-4 & $100.0 \pm 0.0 \mathrm{a}$ & Susceptible & Adapted \\
\hline \multirow[t]{5}{*}{ Gowa } & TN1 & No resistant gene & $100.0 \pm 0.0 \mathrm{~b}$ & Susceptible & Adapted \\
\hline & IR 46 & Glh-1 & $100.0 \pm 0.0 \mathrm{~b}$ & Susceptible & Adapted \\
\hline & Ciliwung & Glh-6 & $100.0 \pm 0.0 \mathrm{~b}$ & Susceptible & Adapted \\
\hline & IR 48 & Glh-5 & $70.0 \pm 15.3 \mathrm{a}$ & Susceptible & Adapted \\
\hline & IR 66 & glh-4 & $80.0 \pm 13.3 \mathrm{a}$ & Susceptible & Adapted \\
\hline \multirow[t]{5}{*}{ Maros } & TN1 & No resistant gene & $100.0 \pm 0.0 \mathrm{c}$ & Susceptible & Adapted \\
\hline & IR 46 & Glh-1 & $100.0 \pm 0.0 \mathrm{c}$ & Susceptible & Adapted \\
\hline & Ciliwung & Glh-6 & $100.0 \pm 0.0 \mathrm{c}$ & Susceptible & Adapted \\
\hline & IR 48 & Glh-5 & $50.0 \pm 16.7 \mathrm{a}$ & Moderately resistant & Not adapted \\
\hline & IR 66 & glh-4 & $80.0 \pm 13.3 \mathrm{~b}$ & Susceptible & Adapted \\
\hline
\end{tabular}

Numbers followed by the same letter in the same column are not significantly different (Duncan's multiple range test, $p>0.05$ ) for the same colony. $*$ Cultivar reactions: Resistant $=0-30 \%$, moderately resistant $=>30-60 \%$ and susceptible $=>60 \%$. $* *$ Adapted $=$ percent of transmission is not significantly different from TN-1, Not adapted = transmission rate is significantly lower than TN-1 
Nur Rosida et al. / OnLine Journal of Biological Sciences 2020, 20 (4): 221.231 DOI: 10.3844/ojbsci.2020.221.231

Table 4: Detection of RTBV and RTSV in weed samples collected from different locations (Pinrang, Sidrap, Gowa and Maros) in South Sulawesi, Indonesia

\begin{tabular}{|c|c|c|c|c|c|c|c|c|c|c|c|c|}
\hline \multirow[b]{2}{*}{ Weed species } & \multirow[b]{2}{*}{$\begin{array}{l}\text { No. samples } \\
\text { (Pinrang) }\end{array}$} & \multicolumn{3}{|c|}{ PCR Result } & \multicolumn{3}{|c|}{ PCR result } & \multicolumn{3}{|c|}{ PCR result } & \multicolumn{2}{|c|}{ PCR result } \\
\hline & & BV & SV & $\begin{array}{l}\text { No. samples } \\
\text { (Sidrap) }\end{array}$ & BV & SV & $\begin{array}{l}\text { No. samples } \\
\text { (Gowa) }\end{array}$ & BV & SV & $\begin{array}{l}\text { No. samples } \\
\text { (Maros) }\end{array}$ & BV & SV \\
\hline Fimbristilys miliacea & 1 & - & - & 1 & - & - & 0 & - & - & 1 & - & - \\
\hline Cyperus iria & 1 & - & - & 0 & - & - & 1 & - & - & 1 & - & - \\
\hline Monochoria vaginalis & 1 & - & - & 0 & - & - & 1 & - & - & 1 & - & - \\
\hline Sphenoclea zeylanica & 0 & - & - & 1 & - & - & 0 & - & - & 0 & - & - \\
\hline Lugwigia octovalvis & 1 & - & - & 1 & - & - & 0 & - & - & 1 & - & - \\
\hline Digitaria sanguinalis & 1 & - & - & 1 & - & - & 0 & - & - & 0 & - & - \\
\hline Echinochloa crusgalli & 1 & - & - & 1 & - & - & 0 & - & - & 0 & - & - \\
\hline Paspalum distichum & 0 & - & - & 0 & - & - & 0 & - & - & 0 & - & - \\
\hline Eleusin indica & 1 & - & - & 1 & - & - & 1 & - & - & 1 & - & - \\
\hline Cyperus rotundus & 0 & - & - & 1 & - & - & 0 & - & - & 1 & - & - \\
\hline Laptocloa chinensis & 1 & - & - & 1 & - & - & 1 & - & - & 1 & - & - \\
\hline Cyperus difformis & 1 & - & - & 1 & - & - & 1 & - & - & 1 & - & - \\
\hline
\end{tabular}

$--=$ No tungro virus detected in a weed sample.

$0=$ no sample and $1=1$ sample of a weed species collected in a sampling site.

$\mathrm{BV}=\mathrm{RTBV}, \mathrm{SV}=\mathrm{RTSV}$
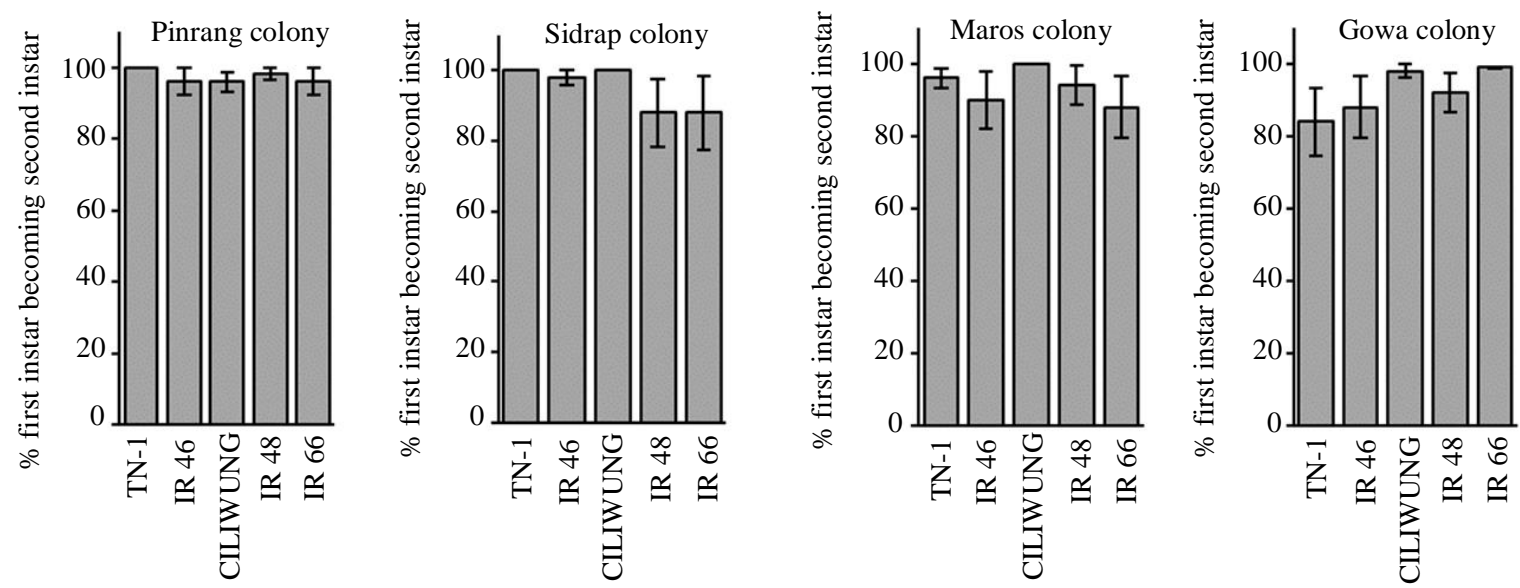

Fig. 1: Mean percent $( \pm$ SEM) of the first instar nymphs successfully developing to second instar nymphs of each colony on TN-1, IR 46, Ciliwung, IR 48 and IR 66
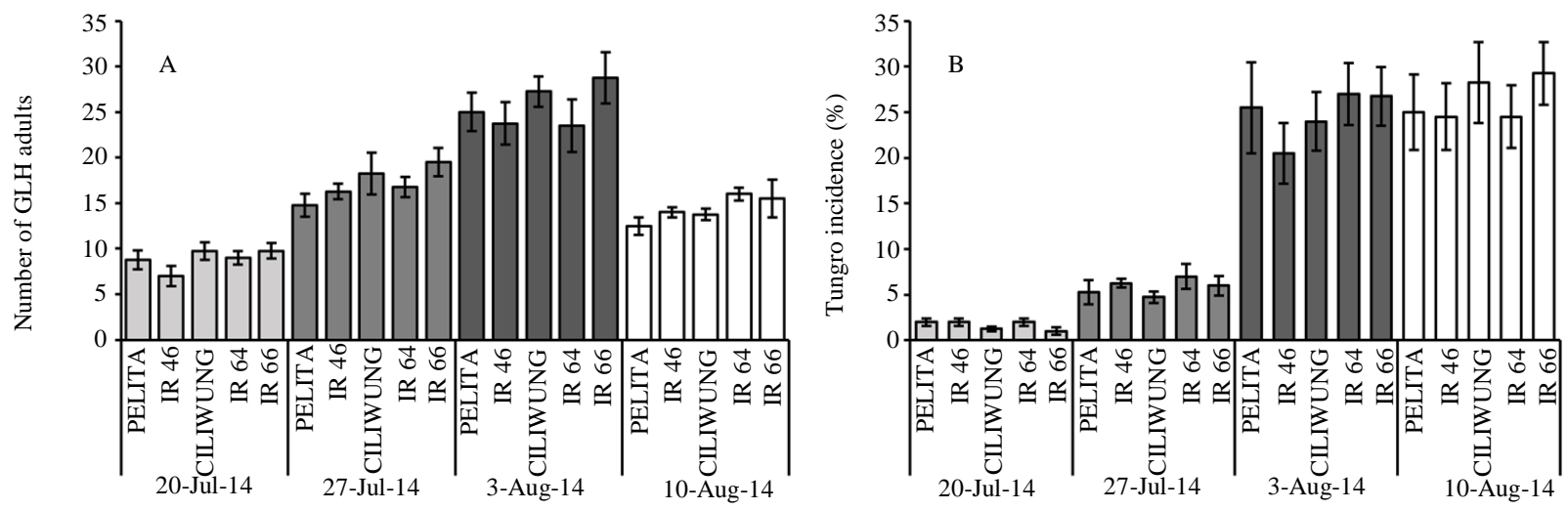

Fig. 2: Number ( \pm SEM) of GLH adults per 20 sweeps (A) and percent of RTV infection (B) on different rice cultivars with different resistance genes against the GLH during four observation dates 

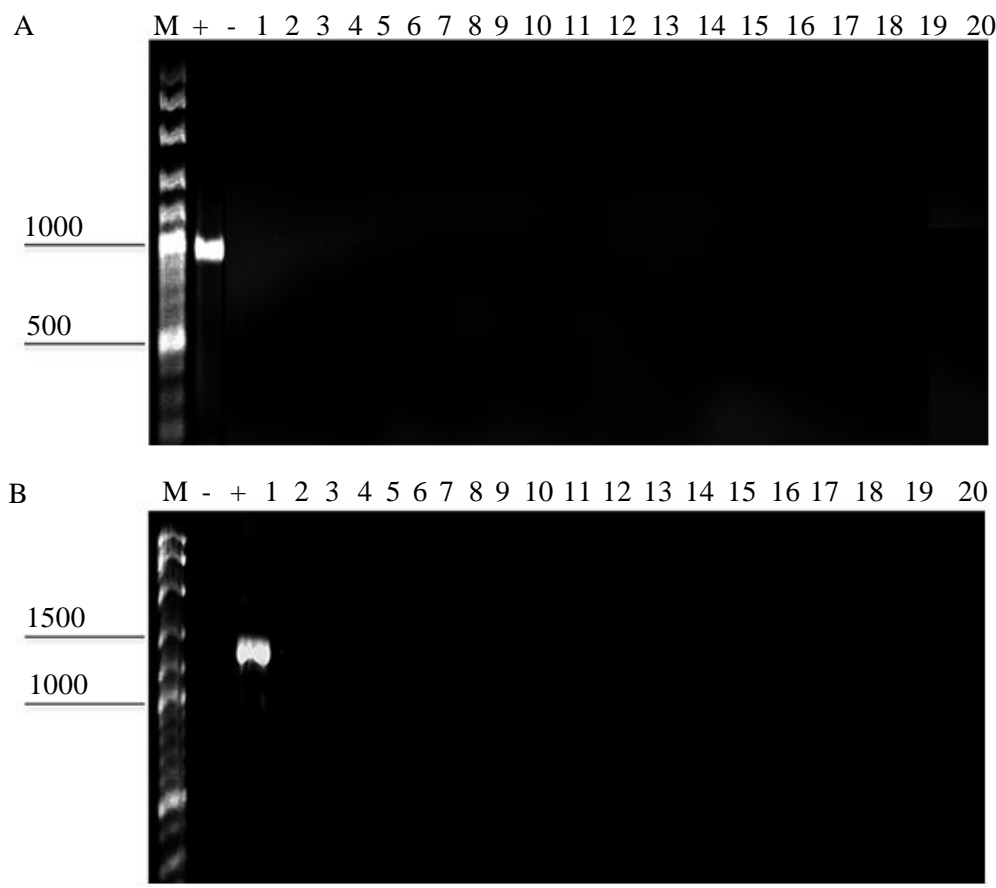

Fig. 3: Agarose gel electrophoresis stained with ethidium bromide for detection of RTSV (A) and RTBV (B) on rice a collected from different locations: 1, 2 and 3 (Pinrang); 4, 5 and 6 (Sidrap); 7, 8, 9 and 10 (Maros); 12, 13 and 14 (Gowa); and on weed: 15, 16 and 17 (Pinrang), 18 (Sidrap); 19 (Maros); and 20 (Gowa);. M = DNA ladder; - = negative control; + = positive control

Table 5: Biotype of the GLH colonies collected from different locations in South Sulawesi Indonesia

\begin{tabular}{|c|c|c|c|c|c|}
\hline \multirow[b]{2}{*}{ Colony } & \multicolumn{4}{|c|}{ Cultivar (resistant gene against GLH) } & \multirow[b]{2}{*}{ GLH biotype* } \\
\hline & IR 46 (Glh-1) & Ciliwung (Glh-6) & IR 48 (Glh-5) & IR 66 (glh-4) & \\
\hline Pinrang & $\mathrm{S}$ & $\mathrm{S}$ & S & MR & 1654 \\
\hline Sidrap & $S$ & $S$ & $S$ & $\mathrm{~S}$ & 1654 \\
\hline Gowa & $S$ & $S$ & $\mathrm{~S}$ & $S$ & 1654 \\
\hline Maros & $\mathrm{S}$ & $S$ & MR & $S$ & 1654 \\
\hline
\end{tabular}

$\mathrm{S}=$ Susceptible

$\mathrm{MR}=$ Moderately resistant

*Biotype categories based on (Widiarta et al., 2013)

\section{Discussion}

Transmission of the rice tungro viruses by $N$. virescens depends on the adaptability of the GLH to cultivars containing resistance genes to the insect vector. The purpose of the rotation of the cultivars with different resistance genes against the vector is to prevent the vector from adapting to a certain resistance gene, thus the GLH populations are suppressed and consequently, the RTV incidence is also reduced (Sama et al., 1991; Widiarta, 2014). The GLH adaptability to a resistance gene can be assessed based on percent of first instars developing to second instars nymphs (Hirae et al., 2007), nymphal development index (Cook, 1991), ability to transmit RTV in seedling test (Widiarta et al., 2013) and the GLH population and RTV incidence in the field (Heinrichs and Rapusas, 1983; Yuliani, 2014). An insect colony is considered adapting to a certain resistance gene if these parameters on the cultivar carrying the gene are not significantly different from those on a cultivar without a resistance gene, such as TN-1.

Our results indicated that all $N$. virescens colonies tested had adapted to all cultivars carrying different resistance genes against the leafhopper. For each colony, there were no significant differences in percent of first instars developing to the second instar nymphs on all resistant cultivars in comparison to $\mathrm{TN}-1$ (Fig. 1). Nymphal development indices of each colony on cultivars with resistance genes were not significantly different from its development index on TN-1 (Table 2). The no-choice seedling test showed that none of the tested cultivars were resistant against the GLH colonies. Only IR 66 and IR 48 reacted moderately resistant to 
Pinrang and Maros colonies, respectively. Similarly, for all colonies, there were no significant differences in GLH populations and rice tungro incidences on cultivars with GLH resistance genes in comparison to the population and disease incidence on TN-1 (Fig. 2).

Widiarta et al. (2013) introduced a GLH biotype code system. Nephotettix virescens colony adapted to Glh-1 only is Biotype 1000, adapted to Glh-1 and GLH-6 is Biotype 1600, adapted to Glh 1, GLH-6 and GLH-5 is Biotype 1650 and adapted to all resistance genes: Glh-1, GLH-6, GLH-5 and glh-4 is Biotype 1654. None of the tested cultivars with different resistant genes reacted resistantly to any of the GLH colonies, hence all colonies tested in this experiment had adapted to the cultivars (Biotype 1654) (Table 5). Therefore, dominant GLH biotype in South Sulawesi has shifted from Biotype 1050 (Widiarta et al., 2013) to Biotype 1654. Biotype 1654 has also been reported dominant in the Province of Nusa Tenggara Barat (Widiarta et al., 2013). The current study results also showed that there was no a dominant biotype against single resistance gene in the field as the result of the abandonment of the cultivar rotation practice in 1990 's, as a result from the absence of selection pressure of a certain resistance gene on the GLH population.

The RTV infection rate is affected by the vector population, virus source and susceptible host (Dey, 2016). The fluctuation pattern of the leafhopper populations in Maros (west coast) and Sidrap (east coast) during the wet and dry planting seasons in 2019 (Fig. 2) was similar to the GLH population fluctuations recorded by (Sama et al., 1991). However, GLH population during the study (2019) was far lower than the population in 1985. The population peaks in 2019 was 22.5 leafhopper adults per 20 sweeps, while in 1985 , the population peak was 430 leafhopper adults per 10 sweeps (Sama et al., 1991). The low population is probably due to the intensive use of insecticide to control other important rice pests, including brown rice planthopper (Gunawan et al., 2015) and rice stem borer (Baehaki, 2015).

The PCR procedures showed that none of the weed species contain RTBV or/and RTSV. Ladja (2013) reported that four weed species collected from rice field in Sidrap, namely: Cyperus rotundus, Phyllanthus niruri Fimbristylis miliaceae and Eulisine indica, were infected by rice tungro virus and acted as effective inoculum sources for rice infection. One of the weeds, Phyllanthus niruri was not present in the field during the current study, however, no rice tungro virus was detected on the other three species. The lack of viruses on the weeds is probably due to the introduction of resistant rice cultivars to rice tungro viruses, such as Tukad Balian, Tukad Petanu, Tukad Unda and Bondoyudo since the early 2000's. More tungro-resistant cultivars have been introduced ever since (Sari et al., 2013). In addition, we also recognize that the weed populations were low during the study, which is probably due to the intensive use of herbicide during the soil cultivation and farmers' practice of field inundation for 2- Sari weeks before planting. The lower weed populations probably affect the availability of RTV inoculum and GLH population during the fallow period.

\section{Conclusion}

The study results suggested that the lack of rice RTD inoculum sources, lower GLH population and the widespread use of resistant cultivars against RTV were the main reasons why tungro incidence decreases from time to time in South Sulawesi, although the recommendations for the appropriate planting time and cultivar rotation are no longer practiced by the farmers. Our results also suggested that if the rice tungro viruses are reintroduced to the region, then the RTV can become devastating because the GLH colonies have already adapted to all available resistance genes. To anticipate the possible reoccurring epidemics in the future more cultivars with new resistance genes to the GLH and RTV should be developed.

\section{Acknowledgement}

The study was financially supported by the Indonesian Agency for Agricultural Research and Development, Ministry of Agriculture, Republic of Indonesia. We thank the Indonesian Rice Tungro Research Center and the National Rice Research Institute for providing the rice seeds necessary to conduct the study. We also thank Yusran Arifin for the technical assistance provided during the study.

\section{Authors' Contributions}

Nur Rosida: Conceptualized the research performed the experimental work designed the research methodology prepared the original draft acquired the funding.

Tutik Kuswinanti: Conceptualized the research designed the research methodology, critically reviewed the manuscript draft and organized all research activities.

Nur Amin: Conceptualized the research, designed the research methodology, and critically reviewed the manuscript draft.

Andi Nasruddin: Conceptualized the research, performed the experimental work, designed the research methodology, and prepared the original draft.

\section{Ethics}

The authors declare no conflict of interest related to the submitted manuscript. 


\section{References}

Anjaneyulu, A., Shukla, V. D., Rao, G. M., \& Singh, S. K. (1982). Experimental host range of rice tungro virus and its vectors. Plant Disease, 66(1), 54-56.

Azzam, O., Cabunagan, R. C., \& Chancellor, T. (2000). Methods for evaluating resistance to rice tungro disease (No. 2169-2019-1612).

Baehaki, S. E. (2015). Hama penggerek batang padi dan teknologi pengendalian. Iptek Tanaman Pangan, 8(1), $1-14$.

BBPOPT. (2019). Prakiraan serangan tungro di Indonesia MT 2019-2020. BBPOPT. https://bbpopt.id/index.php/2020/04/09/prakiraanserangan-tungro-di-indonesia-mt-2019-2020/

Bunawan, H., Dusik, L., Bunawan, S. N., \& Amin, N. M. (2014). Rice tungro disease: From identification to disease control. World Appl Sci J, 31(6), 1221-1226.

Burhanuddin. (2006). Keadaan terkini penyakit tungro di Sulawesi Selatan dan strategi pengendaliannya. Loka Penelitian Penyakit Tungro http://lolittungro.litbang.pertanian.go.id/images/pros iding/burhanuddin2007.pdf

Burhanuddin, Widiarta, I. N., \& Hasanuddin, A. (2006). Penyempurnaan Pengendalian Terpadu Penyakit Tungro dengan Strategi Menghidari Infeksi dan Pergiliran Varietas Tahan. Jurnal Hama dan Penyakit Tumbuhan Tropika, 6(2), 92-99.

Cook, A. G. (1991). Methods to evaluate the variability of rice leafhopper and planthopper populations. In Rice Insects: Management Strategies (pp. 215-233). Springer, New York, NY.

Dey, S. R. (2016). Green Leafhopper (GLH), Nephotettix Virescens (Distant) and Rice Tungro Disease (RTD). The Beats of Natural Sciences, 3(3-4).

DITLIN, (2019). Laporan Serangan OPT dan DPI Direktorat Perlindungan Tanaman Pangan Periode 11 Oktober 2019 (Luas Serangan Organisme Penganggu Tumbuhan (OPT) Utama pada Tanaman Padi). http://ditlin.tanamanpangan.pertanian.go.id/index.ph p/artikel/opt_dan_dpi

Gunawan, C. S. E., Mudjiono, G., \& Astuti, L. P. (2015). Kelimpahan populasi wereng batang coklat Nilaparvata lugens Stal.(Homoptera: Delphacidae) dan laba-laba pada budidaya tanaman padi dengan penerapan pengendalian hama terpadu dan konvensional. Jurnal Hama dan Penyakit Tumbuhan, 3(1), pp-117.

Heinrichs, E. A. (1985). Genetic evaluation for insect resistance in rice. Int. Rice Res. Inst.

Heinrichs, E. A. \& Rapusas, H. (1983). Correlation of resistance to the green leafhopper, Nephotettix virescens (Homoptera: Cicadellidae) with tungro virus infection in rice varieties having different genes for resistance. Environmental Entomology, 12(1), 201-205.
Hibino, H. (1987). Rice tungro virus disease: current research and prospects. In Workshop on Rice Tungro Virus, Maros (Indonesia), 24-27 Sep 1986. BALITTAN Maros.

Hibino, H., Roechan, M., \& Sudarisman, S. (1978). Association of two types of virus particles with penyakit habang (tungro disease) of rice in Indonesia. Phytopathology, 68(10), 1412-1416.

Hirae, M., Fukuta, Y., Tamura, K., \& Oya, S. (2007). Artificial selection of biotypes of green rice leafhopper, Nephotettix cincticeps Uhler (Homoptera: Cidadellidae) and virulence to resistant rice varieties. Applied entomology and zoology, 42(1), 97-107.

Ladja, F. (2013). Gulma inang virus tungro dan kemampuan penularannya ke tanaman padi. Jurnal Penelitian Pertanian Tanaman Pangan, 32(3), 187-191.

Ladja, F. T., Hidayat, S. H., Damayanti, T. A., \& Rauf, A. (2016). Deteksi virus tungro pada gulma padi sawah menggunakan teknik PCR. Jurnal Penelitian Pertanian Tanaman Pangan, 35(1), 39-44.

Nasruddin, A., Rahim, M. D., \& Fatahuddin. (2016). Seasonal abundance and species composition of Nephotettix spp., in endemic and non-endemic areas of rice tungro virus disease in South Sulawesi Province, Indonesia. Online J. Biol. Sci., 16: 130 -136.

Praptana, H. R. \& Muliadi, A. (2013). Durabilitas Ketahanan varietas padi terhadap penyakit tungro. J. Iptek Tanaman Pangan, 8: 15-21. http://ejurnal.litbang.pertanian.go.id/index.php/ippa n/article/view/2554

PUSDATIN, (2017). Statistik Iklim, Organisme Penganggu Tanaman dan Dampak Perubahan Iklim. Pusat Data dan Sistem Informasi Pertanian Sekretariat Jenderal-Kementerian Pertanian, Jakarta.

Sama, S., Hasanuddin, A., Manwan, I., Cabunagan, R. C., \& Hibino, H. (1991). Integrated rice tungro disease management in South Sulawesi, Indonesia. Crop Protection, 10(1), 34-40.

Sari, D., Nurdin, M., \& Aeny, T. N. (2013). Uji Ketahanan Beberapa Varietas Padi terhadap Virus Tungro. Jurnal Agrotek Tropika, 1(3), 331-335.

Suprihanto, Nurhayati, E., \& Harjosudarmo, J. (2013). Virulensi isolat rice tungro virus dari beberapa daerah endemis tungro di Indonesia. J. Fitopatologi Indonesia, 9(1), 29-37. https://core.ac.uk/download/ pdf/230403065.pdf

Tiongco, E. R. \& Sebastian, L. S. (2008). A tale of two viruses. In: The rice tungro virus disease, A paradigm in Disease Management. Tiongco ER, Angeles ER, Sebastian LS (Eds.). Philippine Rice Research Institute. p.1-14. 
van Regenmortel, M. H., Fauquet, C. M., Bishop, D. H., Carstens, E. B., Estes, M. K., Lemon, S. M., \& Wickner, R. B. (2000). Virus taxonomy: classification and nomenclature of viruses. Seventh report of the International Committee on Taxonomy of Viruses. Academic Press.

Widiarta, I. N. (2005). Wereng hijau (Nephotettix virescens Distant): dinamika populasi dan strategi pengendaliannya sebagai vector penyakit tungro. J. Litbang Pertanian, 24(3), 85-92.

Widiarta, I. N. (2014). Strategi Pengendalian terpadu penyakit tungro berdasarkan dinamika populasi vektor, patologi, dan epidemiologi virus. Jurnal Penelitian dan Pengembangan Pertanian, 33(2), 61-68.
Widiarta, I. N., Bastian, A., \& Pakki, S. (2013). Variation in rice tungro virus transmission ability by green leafhopper, Nephotettix virescens Distant (Homoptera: Cicadellidae) on rice resistant varieties. Indonesian J. Agric. Sci., 15(2), 65-71.

Widiarta, I. N., Kusdiman, D., Siwi, S. S., \& Hasanuddin, A. (2004). Varian efikasi penularan tungro oleh kolonikoloni wereng hijau Nephotettix virescens Dist.. J. Entomol. Ind., 1, 50-56. https://peipusat.org/jurnal/index.php/jei/article/view /312

Yuliani, D. (2014). Kelimpahan wereng hijau, insiden penyakit tungro, dan efektivitas sumber inokulum pada ketinggian tempat berbeda. Jurnal Ilmu Pertanian Indonesia (JIPI), 19(3), 125-129. https://journal.ipb.ac.id/index.php/JIPI/article/vie w/9145 